\title{
Windshield glass fragment mimicking a nasal fracture
}

\author{
Fragmento de parabrisas mimetizando fratura nasal \\ Fragmento de vidrio del parabrisas que imita una fractura nasal \\ Marcelo Zillo MARTINI ${ }^{1}$ \\ Shajadi Carlos PARDO-KABA ${ }^{2}$ \\ Juliana SEO $^{3}$ \\ Plinio Jun Iti YOKOYAMA ${ }^{4}$ \\ Fernando Kendi HORIKAWA ${ }^{5}$ \\ Iron Ricardo Machado SNIDEI ${ }^{6}$ \\ Elio Hitoshi SHINOHARA \\ ${ }^{I}$ DDS, PhD, Assistant Surgeon. OMF Surgery Dept. Conjunto Hospitalar do Mandaqui- SUS/SP. Sao Paulo, Brazil \\ ${ }^{2}$ DDS, PhD Assistant Surgeon. OMF Surgery Dept. Hospital Geral de Vila Penteado “Dr. José Pangella” - SUS/SP. São Paulo, Brazil \\ ${ }^{3}$ DDS, PhD Private Practice. Sao Paulo, Brazil \\ ${ }^{4}$ DDS Trainee in OMF Surgery. The Square Dental Radiology. Cotia, Brazil. \\ ${ }^{5}$ DDS, PhD Assistant Surgeon. OMF Surgery Dept. Hospital Regional de Osasco “Dr. Vivaldo Martins Simoes” - SUS/SP. Osasco, Brazil \\ ${ }^{6}$ DDS, MD Head. OMF Surgery Dept. Hospital Regional de Osasco "Dr. Vivaldo Martins Simoes” - SUS/SP. Sao Paulo,Brazil \\ ${ }^{7}$ DDS, PhD Assistant Surgeon. OMF Surgery Dept. Hospital Regional de Osasco “Dr. Vivaldo Martins Simoes” - SUS/SP. Osasco, Brazil, \\ Post-Graduate Program- Universidade Ibirapuera, Sao Paulo, Brazil
}

\begin{abstract}
A male patient with facial trauma by road traffic accident arrived in the emergency room and he was assisted by the Trauma and Neurosurgery team. After clinical evaluation a frontal sinus anterior wall fracture plus a nasal fracture were diagnosed. On the primary OMS examination was checked multiple facial lacerations and gross nasal dorsum deviation with pain, nasal airway obstruction and crepitus with clinical diagnosis of a nasal fracture. After radiologic exam a piece of windshield glass that was superimposed on the nasal bones simulating a nasal fracture was visualized. This paper presents clinical data and literature review of foreign body mimicking facial fractures.

Descriptors: Accidents, Traffic; Facial Injuries; Glass.

Resumo

Paciente do sexo masculino com trauma facial por acidente de trânsito foi avaliado na sala de emergência e foi atendido pelas equipes de Trauma e Neurocirurgia. Após avaliação clínica, foi diagnosticada fratura da parede anterior do seio frontal e fratura nasal. No exame facial foram verificadas múltiplas lacerações faciais e desvio do dorso nasal com dor, obstrução das vias aéreas e crepitação com diagnóstico clínico de fratura nasal. Após o exame radiográfico visualizou-se fragmento de vidro do pára-brisa que estava sobreposto nos ossos nasais simulando fratura. Este artigo apresenta dados clínicos e revisão de literatura de corpo estranho, mimetizando fraturas faciais.

Descritores: Acidente de Trânsito; Traumatismos Faciais; Vidro.

\section{Resumen}

Un paciente masculino con trauma facial por accidente de tráfico llegó a la sala de emergencia y fue asistido por el equipo de Trauma and Neurocirurgia. Después de la evaluación clínica, se diagnosticaron fracturas de la pared anterior del seno frontal más una fractura nasal. En el examen primario de OMS se verificaron múltiples laceraciones faciales y desviación neta del dorso nasal con dolor, obstrucción nasal de las vías aéreas y crepitación con diagnóstico clínico de fractura nasal. Después del examen radiológico, se visualizó un trozo de vidrio del parabrisas superpuesto a los huesos nasales que simulaba una fractura nasal. Este artículo presenta datos clínicos y revisión de la literatura de cuerpos extraños que imitan fracturas faciales.
\end{abstract}

Descriptores: Accidentes de Tránsito; Traumatismos Faciales; Vidrio.

\section{INTRODUCTION}

Motor vehicle accident causing facial trauma can result in the penetration of dental fragments, restorative materials, glass, small rocks, dust, pieces of wood and even road paviment inside the soft tissues leading to pain, inflammatory reactions and abnormal soft tissue healing. The possibility to visualize the foreign body on radiographs depends on its radiopacity and adjacent structure relationship ${ }^{1}$. Literature reports describe foreign bodies in the face simulating dental root fragment ${ }^{2}$ and radiographic image of a bone fracture ${ }^{3}$; but no case of a foreign body mimicking a nasal fracture, clinical and radiographically, was found in the literature. We present a case report of a patient with a windshield glass fragment that simulated a nasal fracture.

\section{CASE REPORT}

A 31 year-old male patient was evaluated in the Oral and Maxillofacial Surgery Department in a level I trauma hospital in Sao Paulo city, Brazil, presenting facial trauma as the result of a motor vehicle accident that occurred 4 days ago. On the day of the accident he was evaluated by the trauma surgeon and a neurosurgical consultation was requested. The diagnostic after clinical evaluation was a frontal sinus (anterior wall) fracture and a deviated nasal fracture.

On the OMF physical examination the patient presented a soft tissue laceration on the middle of his face with nasal airway passage obstruction, crepitating on palpation with pain and gross deviation of the nasal dorsum (Figure1). On the primary care debridement, removal of multiple glass fragments, cleaning of the wounds and suture under local anesthesia were accomplished. Radiographic examination (Water's and soft tissue profile) suggested positioned nasal dorsum and foreign bodies in the naso-frontal region (Figure 2). The final diagnosis was frontal sinus anterior wall fracture, positioned nasal fracture and windshield glass fragments in the naso-frontal region.

The planned surgical procedure was exploration and debridement of the wounds under general anesthesia, removal of foreign bodies, 
reduction and fixation of the frontal sinus fracture. During the exploration of the wounds we found a piece of windshield glass over the nasal lateral wall measuring approximately $1,5 \times 0,8 \times 0,3 \mathrm{~cm}$ that was showed the nasal dorsum deviation. We proceed with the debridement, cleaning and fixation of the frontal sinus fracture and suture of the soft tissues (Figure 3). The postoperative period was uneventful and the patient was sent home on the second day after the procedure. On subsequent evaluations all the soft tissue and frontal fracture healed without suppuration or disturbed inflammatory reactions.

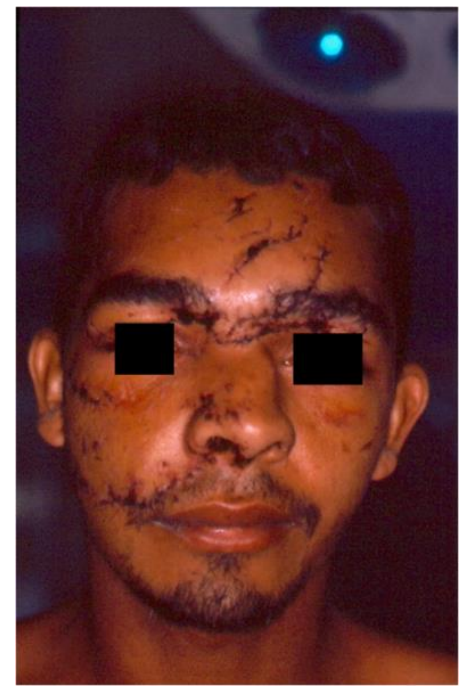

Figure 1: Gross deviation of the nasal dorsum.
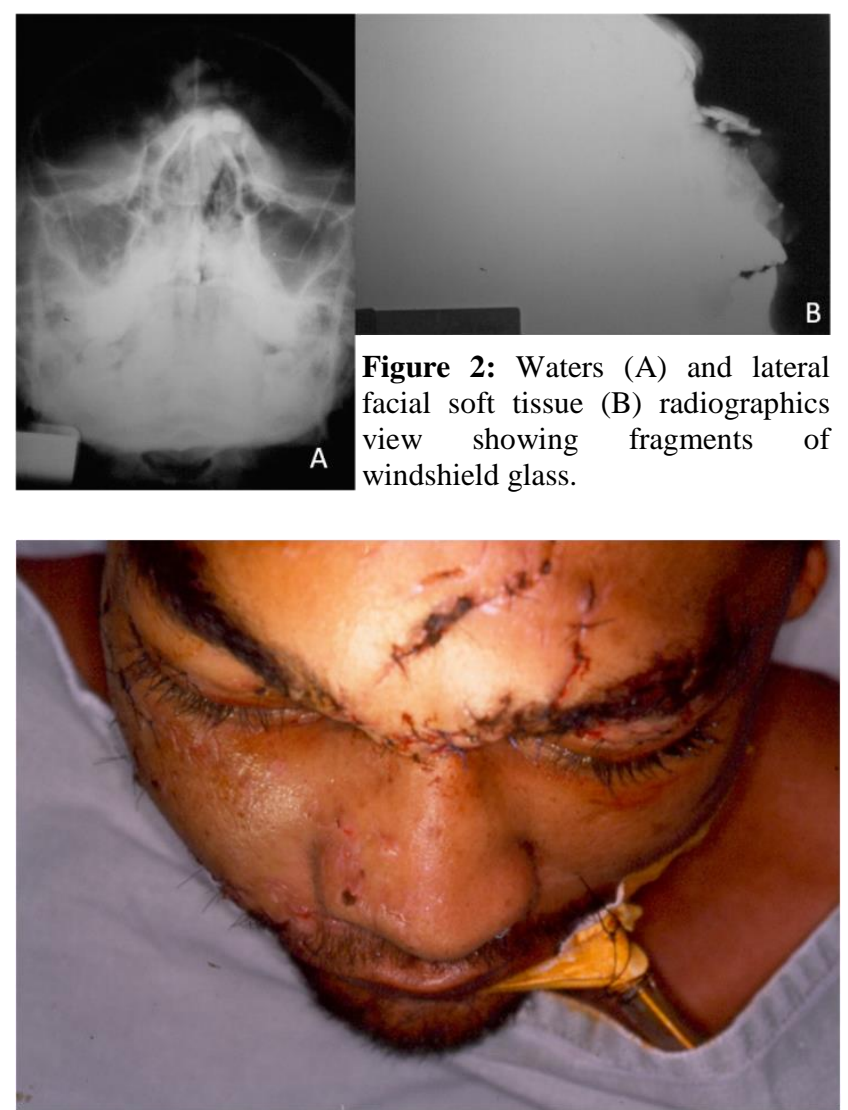

Figure 3: Clinical aspect after remove of foreign bodies showing a normally nasal dorsum.

\section{DISCUSSION}

Motor vehicle accident when passengers are not wearing seat belts frequently result in lacerations in the head and neck area as the consequence of the impact with the windshield glass, and the presence of glass fragments on those injuries are common ${ }^{1,2,4}$. However foreign bodies mimicking facial fractures is uncommon and with almost no reports in the literature $^{3}$. The presence of foreign bodies superimposed to adjacent structures on radiographs can lead to a misdiagnose ${ }^{2}$. On this particular case all the signs, symptoms and clinic examination were strongly suggestive of nasal fracture with the presence of foreign bodies in the adjacent region.

It is never enough to emphasize the difficulty and importance of the diagnostic process in all cases, especially those that at a first look seemed like simple cases.

\section{REFERENCES}

1. Mazinis E, Lambrianidis T, Margelos J. Detection of a residual foreign body during root canal treatment. J Endod. 2005;31(9):691-93.

2. Gray ST. Windshield safety glass foreign body masquerading as a root fragment. Dentomaxillofac Radiol. 1994;23(1):49-51.

3. Goldstein E, Gottlieb MA. Foreign bodies in the nasal fossae of children. Oral Surg Oral Med Oral Pathol. 1973;36(3):446-47 .

4. Madhere S, Barba CA, Painter RL, Morgan AS. Aspiration of shattered windshield glass after blind nasotracheal intubation in a motor vehicle crash. J Trauma. 1997;43:353-56.

\section{CONFLITS OF INTERESTS}

The authors declare no conflicts of interests.

\section{CORRESPONDING AUTHOR}

\section{Elio Hitoshi Shinohara}

elioshinohara@yahoo.com.br 